\title{
Finance Perspective versus Accounting Perspective: The Case of Earnings Persistence in Indonesia
}

\author{
BANDI \\ Correspondence: BANDI, Universitas Sebelas Maret, Indonesia \\ Received: May 14, 2012 \\ Accepted: June 25, 2012 \\ Online Published: August 7, 2012 \\ doi:10.5539/ijef.v4n9p191 \\ URL: http://dx.doi.org/10.5539/ijef.v4n9p191
}

\begin{abstract}
This study aims at comparing accounting and finance perspective to predict earnings persistence. Accounting perspective predicts that current earning components affect the future earnings, while finance perspective predicts that current dividends affect the future earnings. The results show that component of earnings more persistence rather than total earning, and persistence of earnings are also showed by changes of dividend. The results of this study that changes in dividend policy have information contents about future earnings. Increase in dividend payment show that firm believe that firm have better prospect in the future thus able to achieve better future performance. This result confirm prospect theory. This research also find manager use dividend policy to convey relevant information to investor. Managers believe that firms have good opportunity in the future and achieve higher performance. In this case, managers pays higher dividend to give signal to investor that firm will achieve better performance. Firms using dividend policy to give signal to investor to convey relevant information. This result confirm dividend signalling theory. The results also confirm agency theory studying the relationship between management (agent) and shareholder (principal) and assuming the more unite the shareholder, the more powerful shareholders' position rather management's position. The principal interested to both earnings distribution and increasing in future earnings, whereas management prefer increasing permanent earnings with increasing investment on prospective project rather than dividing dividend. The findings of the study show that increase in current earnings and dividend indicates increase in future earnings and dividends. The results of the study show that accrual-cash flow perspective better indicating quality of earnings than dividend signaling perspective.
\end{abstract}

Keywords: earnings persistence, prospect theory, signalling, dividend, cash flows, return

\section{Introduction}

Earnings is important information for investor because earnings number shows firm's financial performance. Investor use earnings information to make investment decisions. In order to provide better quality of information, earnings number must have higher quality. There are two proxies of earning quality measure: (1) permanent earnings concept (Anctil \& Chamberlain, 2005; Black, 1980; Ohlson \& Zhang, 1998); and (2) persistent earnings concept (Nichols \& Wahlen, 2004; Penman \& Zhang, 2002; Schipper \& Vincent, 2003). The "persistence" of earnings refer to to the sustainability of current earnings in the future period (Nichols \& Wahlen, 2004; Schipper $\&$ Vincent, 2003). Persistence earnings provide higher quality because investor can use current earnings number to predict future earnings. In this case, investor have more information about future firm performance and able to make better decision making on investment. Thus, more persistence earnings result in more value-relevance for decision making. This study focuses on earnings persistence using Indonesia contexts. Earnings with more sustainable components, that is current earnings sustain in the future earnings, have higher quality. Random walk earnings is highly persistence because future earnings has the same number with current earnings.

There are two perspective on earnings persistence: accounting perspective and finance perspective. Accounting perspective focusing on how accounting earnings affect future earnings, while finance perspective focusing on how dividend policy affect future earnings. Kane et al. (1985) argues that previous research analyze the important of earnings excluding the importance of dividend information. Therefore, they suggest to investigate earnings and dividends simultaneously. Therefore, this study aims at comparing between accounting and finance perspective regarding earning persistence.

Beaver (2002) argues that capital market can be divided into five areas: market effiiency, Feltham-Ohlson modeling, value relevance, behavior analysis and accrual discretion. This study is part of the value relevance 
research. There are three issues in this study: (1) earning persistence, (2) dividend signalling, and (3) timeliness. There are two important proxies to measure timeliness: (1) the difference of statement date with announcement date (Chambers \& Penman, 1984; Dyer \& McHugh, 1975; Whittred, 1980), and (2) earnings reflection on the stock price (Ball, Kothari, \& Robin, 2000; Ball, Robin, \& Wu, 2003; Basu, 1997; Bushman, Chen, Engel, \& Smith, 2004). Research on the timeliness using the second proxies still needs to carry out.

The objective of this study is to examine the effect of current earnings (total earnings and component of earnings: accruals and cash flows) and dividend on the future earnings. Also, this research investigate prospect theory, dividend signalling theory and the usage of earnings through timeliness of earnings information.

\section{Literature Overview and Hypothesis Development}

\subsection{Agency Theory}

Agency theory describe the relationship between two parties: owner as a principal and management as an agent (Jensen \& Meckling, 1976). Owner delegates the authority to manage firm into agent. Therefore, agent (management) manages the company's operation. On the other hand, owner expect that they will get return from firm operation. Agency theory assume that both parties making decision based on their own best interest. Managers prefer to get higher reward, on the other hand owner prefer higher return from their investment. Therefore, agency conflict happens between owner and managers. This agency conflict raise agency cost. It is impossible to eliminate agency cost, but it can be minimize. This study uses earnings as an internal measurement of management performance (Scott, 2009), to explain agent-principal relationship. Based on agency theory, it is expected management try to maximize their return through higher earnings and higher dividend. Owner expect that management able to achieve higher performance, therefore earnings number is increase. Owner also expect that they will receive higher dividend.

\subsection{Dividend Signaling Theory}

There is information assymetry between management and investor regarding firm conditions. Managers running day to day company, therefore they know well about firm conditions. On the other hand investors do not involve on firm operation, therefore they know less about firm conditions. In this case, managers having more information compare to investors. One of option is manager using dividend to deliver relevant information. Managers using dividend to give signal for investors about firm conditions. This is called dividend signalling theory (see, for example:Bhattacharya, 1979; Hartono, 2004 ; John \& Williams, 1985; Miller \& Rock, 1985; Ross, 1977).

Manager uses dividend signal to send information which is not possessed by investors. However, signaling needs cost (Miller \& Rock, 1985). Signaling cost through dividend usually uses productive investment. Logically, it will be too expensive for low quality firm (Amihud \& Li, 2006). If managers believe that firm have more opportunity to growth in the future and to achieve better performance, they will increase dividends. Investor will react positively because this is good news. On the other hand, if firm cut heir dividend, investor will react negatively because this is bad news. Investor reaction on bad news is stronger compare to good news. Thus, dividend policy is important because it is signal from managers to investors regarding firm conditions. Investors use information from dividends policy to make investment decisions. This decision reflected on the stock price around dividend announcements.

\subsection{Prospect Theory}

Prospect theory is Judgment and decision making (JDM) theory developed by Kahneman and Tversky (1979) and Tversky and Kahneman (1981). JDM theory discusses about decision making under uncertainty. It also indicates that people consider many alternatives of decision based on psychology principle rather than economics principle (Kahneman \& Tversky, 1979; Koonce \& Mercer, 2005; Tversky \& Kahneman, 1981).

Prospect theory predicts that firm not able to report positive earnings will take big baths by (a) including all loss possibility, and (b) excluding all possible earnings from current year earnings (Koonce \& Mercer, 2005). Thus, firm that engage in big bath suffer from bigger loss in the current year. However, they can achieve better performance in the next year. Thus, firm able to shows significant improvements after suffer from bigger losses. This behaviour based on assumption that investors will prefer to invest in the firms having a series of small earnings than firms that experience fluctuate earnings (Matsumoto, 2002). Prospect theory explains why manager might manage earnings to avoid small loss in the reporting (Burgstahler \& Dichev, 1997). It also explains that firms known to be able to manage earnings, as far as possible to include predicted future loss in the statement of current period.

Furthermore, prospect theory explains two effects, certainty effect and reflection effect (Kahneman \& Tversky, 
1979; Koonce \& Mercer, 2005). Certain effect predicts that people valued possible return too high, relative to probable return. Based on the assumption, premise can be formulated that management will report his/her persistent earnings (certainty effect) or increase his/her accrual so that the earnings is persistent instead of suffers from loss even just in small amount or even decrease the dividends (reflection effect).

\subsection{Hypothesis Development}

There are two approaches to investigate persistence of earnings that meet qualitative requirement: accounting approach and finance approach. Accounting approach is based on accrual. Accrual earnings have reverting characteristic. For example if in period $t$ accrual increases, period $t+1$ accrual will decrease and vice versa. Sloan (1996) finds that accrual components of earnings are less persistent than cash flow component of earnings. Financial approach is based on firm's dividend policy. Study about dividend can be carried out as study on how market react to the announcement of dividend payment that is commonly called as dividend signaling (Koch \& Sun, 2004) and information content of dividend about future earnings (Nichols \& Wahlen, 2004).

There are two agency costs based on the relationship between parties within firms: (a) agency cost because conflict between owner and management (agency-equity relationship), and (b) conflict between shareholder and bondholder (agency-debt relationship) (Eisendhardt, 1989; Shane, 1996). Agency theory predicts that owner want to maximize their return through dividend policy, thus they force managers to make dividend policies based on owners interest.

Based on signaling theory it can be argued that high quality firms will produce persistent earnings while low quality firms will produce non-persistent earnings. Investors prefer to give premium value to firms with high quality earnings, while making discount on firms with low quality firms. To reach high value from investors, management has incentive to implement prospect theory in such a way that the earnings look persistent. Another way is to change their dividend policy and then receive share value higher then what should be obtained. This research examine component of firm's earnings to disclose implementation of prospect theory.

Based on assumption of prospect theory, investors prefer to invest in the firms having persistent earnings than firms with fluctuate earnings (Koonce \& Mercer, 2005). Management uses his discretion to achieve certain numbers of earnings. As a result, the earnings will be persistent instead of high level of earnings followed by decrease of earnings (certainty effect). For firms showing decrease of earnings or even loss, they will manage their accrual so that earnings in their report will be positive and look persistent (reflection effect).

Hypothesis testing in this research is divided into three stages: (1) test of earnings and component of earnings over future earnings, called as "accrual-cash flow" approach, (2) test of dividend over future earnings called as "dividend signaling approach", and (3) test of earnings and dividend over future earnings that is combination of "accrual-cash flow" and "dividend signaling" approach.

\subsection{Accrual-cash Flow Approach}

Nichols and Wahlen (2004) review links between earnings and share prices developed by Beaver (1998). Those three links are (1) current period earnings that provide information to predict future earnings, (2) provide information to develop expectation of future earnings, (3) provide information to give valuation on share price that reflected current value of future dividend. Nichols and Wahlen (2004) find that market reacts stronger to the announcement of firms with higher persistence of earnings rather than firms with low persistence of earnings. Persistence hypothesis is that future earnings will increase and becomes persistent relative from previous earnings. Based on the literature review the first hypothesis of the research is stated as follows:

$H_{l a}$ : Current earnings affect future earnings,

$H_{l b}$ : Cash flow component of current earnings and Accrual component of current earnings affect future earnings.

These Hypotheses can be modeled as follows.

$$
\begin{aligned}
& \mathrm{H}_{1 \mathrm{a}} \text { : } \text { Earning }_{t+1}=\alpha_{0}+\alpha_{1} \text { Earning }_{t}+v_{t+1} \text {. } \\
& \mathrm{H}_{1 \mathrm{~b}} \text { :Earning }_{t+1}=\alpha_{0}+\alpha_{2} \text { Cashfl }_{t}+\alpha_{1} \text { Accrual }_{t}+v_{t+1}
\end{aligned}
$$

\subsection{Dividend Signaling Approach}

Dividend signaling theory argues that managers use dividend as a signal to investor about firm future prospect. Therefore, dividend has information content to the investor. Investor will react to the announcement of dividend payment. Investors react positively to the announcement of positive dividend changes, because investor believe that firm has good future prospect. However empirical evidence provide mixed result, there are researches provide evidence that dividends have information content to the investors and market reacts significantly to the 
announcements of dividend, e.g. Pettit (1972, 1976); Laub (1976); Charest (1978); Aharony and Swary (1980); Asquith and Mullins (1983); Brickley (1983); Eddy and Seifert (1992); Denis, Denis, and Sarin (1994); Michaely, Thaler and Womack (1995); Ho and Wu (2001); Koch and Sun (2004); Gunasekarage and Power (2002); and Brief and Zarowin (1999). On the other hand, there are evidence market do not react to the announcement of dividend

Other prior researches find a different evidence, for example: Watts (1973); Gonedes (1978); Penman (1983); DeAngelo, DeAngelo, and Skinner (1996); and Amihud and Li (2006). They find that dividend contents few of information. Even though, Benartzi, Michaely and Thaler (1997) find that dividend does not have signaling implication to future earnings. (Gonedes, 1978; Brooks, 1996). Benartzi, Michaely and Thaler (1997) find that dividend does not have signaling implication to future earnings.

Dividend signaling approach assumes that management is reluctant to change his dividend policy and dividend use as signaling is expensive (Amihud \& $\mathrm{Li}, 2006$ ). On the other hand, certainty effect in prospect theory assumes that management prefer profit while reflection effect of prospect theory is that management prefer lower risk rather than possibility of earnings that is uncertain. Therefore, it is expected that changes of dividend will be followed by changes of future earnings as reflection of firm prospective. Thus, next hypothesis of the research is stated as follows:

\section{$\mathrm{H}_{2}$ : Current dividend affects future earnings.}

This hypothesis can be modeled as follows.

$$
\mathrm{H}_{2}: \text { Earning }_{t+1}=\alpha_{0}+\alpha_{1} \text { Div }_{t}+\varepsilon_{t+1}
$$

\subsection{Accrual-cash Flow and Dividend Signaling Approach}

Prospect theory assumed that firms with loss that can be measured in the current period will try to move some current earnings into future period (Koonce and Mercer, 2005). Manager use their discretion to manage earnings. Therefore, current earnings become persist. However, it will harm firms if investors detect this discretion. Investors will react negatively and share price will decrease (reflection effect). Therefore it is expected that changes of component of current earnings more show about changes on future earnings than changes on current dividend. Thus, the third hypotheses can be stated as follows:

$H_{3 a}$ : Component of earnings affects more on future earnings than dividend does.

$H_{3 b}$ : Effect of earnings components and stock return to the future earnings more than effect of dividend and stock return to the future earnings.

These Hypotheses can be modeled as follows.

$$
\begin{aligned}
\mathrm{H}_{3 \mathrm{a}}: \text { Earning }_{t+1}= & \alpha_{0}+\alpha_{1} \text { Accrual }_{t}+\alpha_{2} \text { Cash flows }_{t}+\alpha_{3} \text { Div }_{t}+\varepsilon_{t+1} \\
& \mathrm{H}_{3 \mathrm{~b}}: \alpha_{1}>\alpha_{3}, \alpha_{2}>\alpha_{3}
\end{aligned}
$$

Koch and Sun (2004) find that changes of dividend preceded by changes of earnings with the same signal, hence it positively corelate with market reaction around announcement of dividend changes (Sutopo, 2005). Basu (1997) finds that negative changes of earnings was less persistent than positive changes of earnings. Proposition for dividend signaling and earnings information timeliness is that earnings information with increased dividend will be more timeliness, or increased dividend is a signal of future earnings potential. This signal is responded by market resulted in the increase of share price and the increase of return as well, earnings information will be timeline if increase on return accompanied by increase of accounting earnings. Therefore the forth hypotheses can be stated as follows:

$H_{4 a}:$ Future Return, Cash flow component of current earnings, Accrual component of current earnings, and dividend affect future earnings.

$H_{4 b}$ : Effect of Cash flow component of current earnings, Accrual component of current earnings and Future Return on future earnings more than effect of dividend and return on future earning.

These hypotheses can be modeled as follows.

$$
\begin{gathered}
\mathrm{H}_{4 \mathrm{a}}: \text { Earning }_{t+1}=\alpha_{0}+\alpha_{l} \text { RET }_{t+1}+\beta_{l} \text { Div }_{t}+\beta_{2} \text { Cash flows }_{t}+\beta_{3} \text { Accrual }_{t}+\varepsilon_{t+1} \\
\mathrm{H}_{4 \mathrm{~b}}: \beta_{2}+\alpha_{1}>\beta_{1}+\alpha_{1}, \beta_{3}+\alpha_{1}>\beta_{l}+\alpha_{l}
\end{gathered}
$$

\section{Research Method}

\subsection{Population and Sampling and Data Collection}

Research population is all firms listed in Indonesia Stock Exchange (IDX). Sample is chosen by purposive 
sampling that is public firms listed in Indonesia Stock Exchange from 1994 until 2005. The sample based on consideration that length of firm-years observation will cover both booming market condition (before crisis of 1998s) and bearing market condition (since crisis of 1998s). Sample of this research consists of 979 firm-years from 1994 to 2004 period.

\subsection{Variable and Measurement}

Dependant variable is future earnings (Earnings $\mathrm{s}_{\mathrm{t}+1}$ ), including earnings before extra ordinary items. Future earnings are scaled by assets. Future earnings will be regressed to current earnings, component of current earnings, current dividend, and cumulative return.

Independent variable consists of: (1) earnings including earnings before extra ordinary items (Earnings $\mathrm{s}_{\mathrm{t}}$ ), cash flow $_{\mathrm{t}}$ and accrual $\mathrm{l}_{\mathrm{t}}$ component and are scaled by assets; (2) current dividend includes dividend per share (DPS) or its changes; (3) monthly return as difference between share price at month $t$ and price month $t_{-1}$.

\subsection{Hypothesis Testing}

This research uses regression analysis to test hypotheses 1-4. t-test for hypothesis comparing between effect of dividend on future earnings and effect of current and future earnings components. Statistic test also includes test of current earning effect and current dividend on the future earnings, and return effect on future earnings. The test is divided into three stages: (1) Accrual-Cash flow approach, (2) dividend signaling approach, and (3) Accrual-Cash flow and dividend signaling Approach.

\section{Findings and Discussion}

Table 1 shows regression result from equation 1-5.

Table 1. Regression Result

\begin{tabular}{llllll}
\hline & 1 & 2 & 3 & 4 & 5 \\
\hline$\alpha$ & 0.304 & 0.303 & 0.317 & 0.297 & 0.228 \\
& $(43.599)^{*}$ & $(43.546)^{*}$ & $(51.572)^{*}$ & $(43.522)^{*}$ & $(5.807)^{*}$ \\
Earnings $_{\mathrm{t}}$ & 0.195 & & & & \\
& $(7.020)^{*}$ & & & & \\
Accruals $_{\mathrm{t}}$ & & 0.199 & & 0.163 & 0.716 \\
& & $(7.009)^{*}$ & & $(5.964)^{*}$ & $(17.424)^{*}$ \\
Cash Flows $_{\mathrm{t}}$ & & 0.195 & & 0.167 & 0.707 \\
& & $(7.022)^{*}$ & & $(5.94)^{*}$ & $(17.293)^{*}$ \\
Dividend $_{\mathrm{t}}$ & & & 0.282 & 0.0001 & 0.0001 \\
& & & $(7.507)^{*}$ & $(6.495)^{*}$ & $(2.623)^{*}$ \\
Return $_{\mathrm{t}+1}$ & & & & & 0.011 \\
& & & & & $(3.307)^{*}$ \\
$\mathrm{~F}$ & $49.274^{*}$ & $24.865^{*}$ & $56.3 *$ & $31.691^{*}$ & $106.594^{*}$ \\
$\mathrm{R}$ & 0.07 & 0.071 & 0.08 & 0.128 & 0.387 \\
Adj R2 & 0.069 & 0.07 & 0.078 & 0.124 & 0.383 \\
\hline
\end{tabular}

*, ** significant at $1 \%, 5 \%$

Dependent variable is future earnings

\subsection{Accrual-cash Flow Approach}

From table 1 at column 1 and 2 shows the result of the effect of current earnings and component earnings to future earnings. Current earnings (H1a) and component of current earnings: cash flows and accruals affect future earning $\left(\mathrm{H}_{1 b}\right)$. This result shows that current earnings and components of current earnings (accrual and cash flows) have predictive ability. Investors can use current earnings and components of current earnigns to predict future earnings. This result shows that the earnings is persistent because current earnings is sustain in the future earnings. Therefore earnings have higher quality. This can be seen in the increase of adjusted $R^{2}$ from $0,069\left(\mathrm{H}_{1 \mathrm{a}}\right)$ 
to $0,070\left(\mathrm{H}_{1 \mathrm{~b}}\right)$.

\subsection{Dividend Signaling Approach}

From table 1 at column 3, dividend affects future earning $\left(\mathrm{H}_{2}\right)$. This means that dividend have information content to predict future earnings; therefore, dividend information is useful. Increase in dividend payment is a signal that firms have better future prospect. Thus this is good news for investor. This result confirms dividend signalling approach, management use dividend as as ignal of firm future performance. Investor can uses dividend to predict future earnings.

\subsection{Accrual-cash flow and Dividend Signaling Approach}

The result of this research shows that components of current earning (cash flow and accrual) and current dividend affects on the future earnings $\left(\mathrm{H}_{3 \mathrm{a}}\right)$. This means that earning is persistent and can be seen from current dividend and therefore earnings have higher quality. Components of current earnings (coefficient of cash flow beta $=0,1630$, and accrual $=0,1670$ ) explain more about persistence of future earning than current dividend (beta coefficient $=$ 0,0001 , close to zero). Furthermore, simultaneously, components of current earning and current dividend explain more about future earning than current earning, components of current earning and dividend individually. It can be seen from the increase of adjusted $R^{2}$ from 0,069 (current earning, $\mathrm{H}_{1 \mathrm{a}}$ ), from 0,070 (component of current earning, $\mathrm{H}_{1 \mathrm{~b}}$ ), from 0,078 (current dividend, $\mathrm{H} 2$ ) to $0,124\left(\mathrm{H}_{3 \mathrm{a}}\right)$.

The result of analysis in this study at column 5 shows that return, components of current earnings (cash flows and accrual) and current dividend affect future earnings $\left(\mathrm{H}_{3 \mathrm{~b}}\right)$. It means that earnings persist and can be seen from component of current earnings and current dividend, and stock return affects future earnings. Thus, earning is qualified. Component of current earnings and return $(\beta$ cash flow $=0,7180$, and $\beta$ accrual $=0,7270$ ) explain persistence of future earnings more than current dividend does $(\beta=0,0111)$. Beside, return and increase in dividend simultaneously explain usefulness of future earnings (timeliness) more than individually dividend does. It can be seen on increase of adjusted $R^{2}$ from 0,069 (current dividend individually, $\left.\mathrm{H}_{2 \mathrm{a}}\right)$ to $0,383\left(\mathrm{H}_{4 \mathrm{~b}}\right)$.

The result of this research also shows that the firms which retain increase of current dividend, their return affects more on future earning. It means that dividend has predicitive ability to predict future earning. Therefore, dividend information is useful for investors. Dividend has information content about future earnings. Therefore, dividend is important information for investor. Furthermore, this result indicates firms' efforts to increase current dividend so that it can be positive signal for investors to expect future earning. This is consistent with prospect theory that management will increase dividend so that the usefulness of future earning (timeliness) increases.

\section{Conclusion}

This study reject null hypothesis, so it receives alternative hypothesis (hypothesis 1 to hypothesis 4 ). The result shows that the earnings persist, so earnings have higher quality. Persistence increases on component of earnings rather than total earning total. Dividend also provide evidence that it has information content about future earnings. Thus, dividend also shows earnings persistence. The result confirms theory of prospect, that changes in dividend policy have information content about future earnings (certainty effects of prospect theory), because the persistence of earnings are signed by the increase in dividend.

Also, the result support dividend signaling theory that the firms increase their dividend to convey managers expectation that firms have better prospect in the future. Firms also reluctant to cut their dividend, because investor react negatively. Investors will react strongly to bad news compare to good news. This is shows that manager uses dividend announcement to signal the changes of future prospect of firm (Aharony and Swary, 1980); and it also support critique of Kane, et al. (1984) on prior researches on the effect of earnings announcement ignoring the effect of dividend announcement.

The results also confirm agency theory studying the relationship between management (agent) and shareholder (principal) and assuming the more unite the shareholder, the more powerful shareholders' position rather management's position. The principal interested to both earnings distribution and increasing in future earnings, whereas management prefer increasing permanent earnings with increasing investment on prospective project rather than dividing dividend. The findings of the study show that increase in curent earnings and dividend indicates increase in future earnings and dividends.

The results of the study show that accrual-cash flow approach better indicating persistence of earnings and timeliness than dividend signaling approach. This research accrual-cash flow perspective better indicating quality of earnings than dividend signaling perspecitve. 


\section{References}

Aharony, J., \& Swary, I. (1980). Quarterly dividend and earnings announcements and stockholders' returns: An empirical analysis. Journal of Finance, 35(1), 1-12. http://dx.doi.org/10.1111/j.1540-6261.1980.tb03466.x

Amihud, Y., \& Li, K. (2006). The declining information content of dividend announcements and the effects of institutional holdings. Journal of Financial and Quantitative Analysis, 41(03), 637-660. http://dx.doi.org/10.1017/S0022109000002568

Anctil, R. M., \& Chamberlain, S. (2005). Determinants of the Time Series of Earnings and Implications for Earnings Quality. Contemporary Accounting Research, 22(3), 483-517. http://dx.doi.org/10.1506/6D5C-H0VY-FDWL-1URF

Asquith, P., \& Mullins Jr, D. W. (1983). The impact of initiating dividend payments on shareholders' wealth. Journal of Business, 56(1), 77-96. http://dx.doi.org/10.1086/296187

Ball, R., Kothari, S. P., \& Robin, A. (2000). The effect of international institutional factors on properties of accounting earnings. Journal of Accounting and Economics, 29(1), 1-51. http://dx.doi.org/1016/s0165-4101(00)00012-4

Ball, R., Robin, A., \& Wu, J. S. (2003). Incentives versus standards: properties of accounting income in four East Asian countries. Journal of Accounting and Economics, 36(1-3), 235-270. http://dx.doi.org/10.1016/j.jacceco.2003.10.003

Basu, S. (1997). The conservatism principle and the asymmetric timeliness of earnings. Journal of Accounting and Economics, 24(1), 3-37. http://dx.doi.org/10.1016/s0165-4101(97)00014-1

Beaver, W. H. (1998). Financial reporting: An accounting revolution (3 ed.). Upper Saddle River, NJ Prentice Hall.

Beaver, W. H. (2002). Perspectives on recent capital market research. Accounting Review, 77(2), 453-474. http://dx.doi.org/10.2308/accr.2002.77.2.453

Benartzi, S., Michaely, R., \& Thaler, R. (1997). Do changes in dividends signal the future or the past? Journal of Finance, 52(3), http://dx.doi.org/1007-1034. 10.1111/j.1540-6261.1997.tb02723.x

Bhattacharya, S. (1979). Imperfect information, dividend policy, and the bird-in-hand fallacy. The Bell Journal of Economics, 10(1), 259-270. http://dx.doi.org/10.2307/3003330

Black, F. (1980). The magic in earnings: Economic earnings versus accounting earnings. Financial Analysts Journal, 36(6), 19-24. http://dx.doi.org/10.2469/faj.v36.n6.19

Brickley, J. A. (1983). Shareholder wealth, information signaling and the specially designated dividend: An

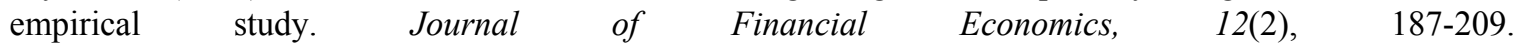
http://dx.doi.org/10.1016/0304-405x(83)90035-1

Brief, R. P., \& Zarowin, P. (1999). The Value Relevance of Dividends, Book Value and Earnings. Retrieved from http://ssrn.com/paper=1281354

Burgstahler, D., \& Dichev, I. D. (1997). Earnings management to avoid earnings decreases and losses. Journal of Accounting and Economics, 24(1), 99-126. http://dx.doi.org/10.1016/S0165-4101(97)00017-7

Bushman, R., Chen, Q., Engel, E., \& Smith, A. (2004). Financial accounting information, organizational complexity and corporate governance systems. Journal of Accounting and Economics, 37(2), 167-201. http://dx.doi.org/10.1016/j.jacceco.2003.09.005

Chambers, A. E., \& Penman, S. H. (1984). Timeliness of reporting and the stock price reaction to earnings announcements. Journal of Accounting Research, 22(1), 21-47. http://dx.doi.org/10.2307/2490700

Charest, G. (1978). Dividend information, stock returns and market efficiency-II. Journal of Financial Economics, 6(2-3), 297-330. http://dx.doi.org/10.1016/0304-405x(78)90033-8

DeAngelo, H., DeAngelo, L., \& Skinner, D. J. (1996). Reversal of fortune dividend signaling and the disappearance of sustained earnings growth. Journal of Financial Economics, 40(3), 341-371. http://dx.doi.org/10.1016/0304-405x(95)00850-e

Denis, D. J., Denis, D. K., \& Sarin, A. (1994). The information content of dividend changes: Cash flow signaling, overinvestment, and dividend clienteles. Journal of Financial and Quantitative Analysis, 29(4), 567-587. http://dx.doi.org/10.2307/2331110 
Dyer, J. C., \& McHugh, A. J. (1975). The timeless of the Australian annual report. Journal of Accounting Research, 13(2), 204-219. http://dx.doi.org/10.2307/2490361

Eddy, A., \& Seifert, B. (1992). Stock price reactions to dividend and earnings announcements: Contemporaneous versus noncontemporaneous announcements. Journal of Financial Research, 15(3), 207-217.

Eisendhardt, K. M. (1989). Agency theory: An assessment and review. The Academy of Management Review, 14(1), 57-74.

Gonedes, N. J. (1978). Corporate Signaling, External Accounting, and Capital Market Equilibrium: Evidence on Dividends, Income, and Extraordinary Items. Journal of Accounting Research, 16(1), 26-79. http://dx.doi.org/10.2307/2490411

Gunasekarage, A., \& Power, D. M. (2002). The post-announcement performance of dividend-changing companies: The dividend-signalling hypothesis revisited. Accounting \& Finance, 42(2), 131-151. http://dx.doi.org/10.1111/1467-629x.00071

Hartono, J. (2004 ). How, Why, and When Investors Revise Their Beliefs to Company Information. Yogyakarta: Penerbit Andi.

Ho, S.-J. K., \& Wu, C. (2001). The earnings information content of dividend initiations and omissions. Journal of Business Finance \& Accounting, 28(7-8), 963-977. http://dx.doi.org/10.1111/1468-5957.00400

Jensen, M. C., \& Meckling, W. H. (1976). Theory of the firm: Managerial behavior, agency costs and ownership structure. Journal of Financial Economics, 3(4), 305-360. http://dx.doi.org/10.1016/0304-405X(76)90026-X

John, K., \& Williams, J. (1985). Dividends, dilution, and taxes: A signalling equilibrium. Journal of Finance, 40(4), 1053-1070. http://dx.doi.org/10.1111/j.1540-6261.1985.tb02363.x

Kahneman, D., \& Tversky, A. (1979). Prospect theory: An analysis of decision under risk. Econometrica, 47(2), 263 - 292. http://dx.doi.org/10.2307/1914185

Koch, A. S., \& Sun, A. X. (2004). Dividend changes and the persistence of past earnings changes. Journal of Finance, 59(5), 2093-2116. http://dx.doi.org/10.1111/j.1540-6261.2004.00693.x

Koonce, L., \& Mercer, M. (2005). Using psychology theories in archival financial accounting research. Journal of Accounting Literature, 24, 175-214.

Laub, P. M. (1976). On the informational content of dividends. Journal of Business, 49(1), 73-80. http://dx.doi.org/10.1086/295811

Matsumoto, D. A. (2002). Management's incentives to avoid negative earnings surprises. Accounting Review, 77(3), 483-514. http://dx.doi.org/10.2308/accr.2002.77.3.483

Michaely, R., Thaler, R. H., \& Womack, K. L. (1995). Price reactions to dividend Initiations and omissions: Overreaction or drift? Journal of Finance, 50(2), 573-608. http://dx.doi.org/10.1111/j.1540-6261.1995.tb04796.x

Miller, M. H., \& Rock, K. (1985). Dividend policy under asymmetric information. Journal of Finance, 40(4), 1031-1051. http://dx.doi.org/10.1111/j.1540-6261.1985.tb02362.x

Nichols, D. C., \& Wahlen, J. M. (2004). How Do Earnings Numbers Relate to Stock Returns? A Review of Classic Accounting Research with Updated Evidence. Accounting Horizons, 18(4), 263-286. http://dx.doi.org/10.2308/acch.2004.18.4.263

Ohlson, J. A., \& Zhang, X. J. (1998). Accrual accounting and equity valuation. Journal of Accounting Research, 36(3), 85-111. http://dx.doi.org/10.2307/2491308

Penman, S. H. (1983). The predictive content of earnings forecasts and dividends. Journal of Finance, 38(4), 1181-1199. http://dx.doi.org/10.1111/j.1540-6261.1983.tb02290.x

Penman, S. H., \& Zhang, X. J. (2002). Accounting conservatism, the quality of earnings, and stock returns. Accounting Review, 77(2), 237-264. http://dx.doi.org/10.2308/accr.2002.77.2.237

Pettit, R. R. (1972). Dividend announcements, security performance, and capital market efficiency. Journal of Finance, 27(5), 993-1007. http://dx.doi.org/10.1111/j.1540-6261.1972.tb03018.x

Pettit, R. R. (1976). The impact of dividend and earnings annoucements: A reconciliation. Journal of Business, 49(1), 86-96. http://dx.doi.org/10.1086/295813

Ross, S. A. (1977). The determination of financial structure: The incentive-signalling approach. The Bell Journal 
of Economics, 8(1), 23-40. http://dx.doi.org/10.2307/3003485

Schipper, K., \& Vincent, L. (2003). Earnings Quality. Accounting Horizons, 17, 97-110. http://dx.doi.org/10.2308/acch.2003.17.s-1.97

Schrand, C. M., \& Walther, B. R. (2000). Strategic benchmarks in earnings announcements: The selective disclosure of prior-period earnings components. Accounting Review, 75(2), 151-177. http://dx.doi.org/10.2308/accr.2000.75.2.151

Scott, W. R. (2009). Financial accounting theory (5 ed.). New Jersey: Prentice-Hall International, Inc.

Shane, S. A. (1996). Hybrid organizational arrangements and their implications for firm growth and survival: A study of new franchisors. The Academy of Management Journal, 39(1), 216-234. http://dx.doi.org/10.2307/256637

Sloan, R. G. (1996). Do stock prices fully reflect information in accruals and cash flows about future earnings? Accounting Review, 71(3), 289-315.

Sutopo, B. (2005). Persistensi Laba dan Pengumuman Perubahan Dividen Sebagai Suatu Sinyal. Jurnal Akuntansi \& Bisnis, 5(2), 187-198.

Tversky, A., \& Kahneman, D. (1981). The framing of decisions and the psychology of choice. Science, 211(4481), 453-458. http://dx.doi.org/10.1126/science.7455683

Watts, R. (1973). The information content of dividends. Journal of Business, 46(2), 191-211. http://dx.doi.org/10.1086/295525

Whittred, G. P. (1980). Audit qualifications and the timeliness of corporate annual reports. Accounting Review, 55(4), 563-577. 